\title{
腎孟尿管腫瘍における膀胱粘膜多部位生検の意義
}

\author{
大阪警察病院泌尿器科（副院長：藤岡秀樹） \\ 辻本裕一波多野浩士 佐藤 元孝 高田 剛 \\ 本多 正人 松宮 清美 藤岡 秀樹

\section{SIGNIFICANCE OF MULTIPLE BIOPSIES OBTAINED FROM BLADDER MUCOSA IN RENAL PELVIC AND URETERAL CARCINOMA}

\author{
Yuichi Tsujimoto, Kohji Hatano, Mototaka Satoh, Tsuyoshi Takada, \\ Masahito Honda, Kiyomi Matsumiya and Hideki Fujioka \\ From the Department of Urology, Osaka Police Hospital
}

(Purpose) We reviewed significance of multiple biopsies obtained from bladder mucosa in 59 patients of renal pelvic and ureteral carcinoma treated at Osaka Police Hospital between 1990 and 2003.

(Materials \& Methods) The patients consisted of 41 males and 18 females. The median age was 68 years, ranging from 42 to 91 years. Multiple biopsies were carried out in principle to examine the following 5 cystoscopically normal-appearing bladder mucosal sites: (1) trigone, (2) posterior wall, (3) left lateral wall, (4) right lateral wall and (5) dome. Positive case of multiple biopsies was defined as patients having abnormalities in at least one biopsy specimen such as bladder tumor (BT) or dysplasia. Median follow-up period was 54 months.

(Results \& conclusions) Of the 59 patients, 6 had positive multiple biopsies. Among them 3 had carcinoma $\mathrm{n}$ situ (CIS), and others had dysplasia. 4 patients with positive multiple biopsies had past or concurrent history of BT and received adjuvant intravesical instillation therapy. Positive rate of multiple biopsies significantly differed between patients with and without past and/or concurrent BT $(4 / 15: 27 \%$ vs $2 / 44: 5 \% \mathrm{p}=0.03)$, indicating that multiple biopsies were useful to detect abnormal lesion accompanied with past and/or concurrent BT. 3-year bladder recurrence free rate was $61 \%$. Postoperative bladder recurrence rate did not significantly differ between positive $(1 / 6$ : $17 \%)$ and negative $(20 / 53: 38 \%)$ cases of multiple biopsies. Univariate analysis indicated stage $(\mathrm{p}=$ $0.03)$ and venous involvement $(p=0.02)$ to be significant prognostic factors for bladder recurrence free rate, but not multiple biopsies, although multivariate analysis with Cox's proportional hazard model revealed no independent prognosticators. Low recurrence rate of patients with positive multiple biopsies was possibly due to adjuvant intravesical instillation therapy to prevent bladder recurrence.

Key words : Renal pelvic and ureteral tumor, multiple biopsies, bladder recurrence

\footnotetext{
要旨：(目的） 1990 年〜2003 年に大阪警察病院で手術を施行した腎孟尿管腫瘍 59 例における膀胱生検 の意義について検討した.

（対象と方法）年齢は 42 91 歳（中央值 68 歳），男性 41 例，女性 18 例であった，膀胱生検は膀胱鏡 で肉眼的に正常な原則 5 力所 (三角部, 後壁, 左側壁, 右側壁, 頂部) について施行した. そのうち 1 カ所でも癌または異形成を認めた場合を生検陽性とし，それ以外は陰性と判定した. 観察期間の中央値 は 54 カ月であった.

（結果）膀胱生検陽性例は 6 例 (10\%) で, G3 の上皮内癌 3 例と異形成 3 例であった. 上皮内癌 3 例の うち 1 例は膀胱癌の既往があり，残りの 2 例は手術時に膀胱癌を合併していた．異形成 3 例のうち 1 例 は手術時に膀胱癌を合併していて，残りの 2 例は膀胱癌を合併していなかった．膀胱生検陽性 6 例のう
} 
ち 4 例 (上皮内癌 ; 3 , 異形成；1）に追加の膀胱内注入療法が施行されていた. 膀胱生検陽性は膀胱癌の 合併歴のない症例 $(2 / 44: 5 \%)$ よりもある症例 (4/15:27\%) のほうが有意 $(\mathrm{p}=0.03)$ に多かった。術 後膀胱内再発は膀胱生検陽性では 1 例 $(1 / 6: 17 \%)$, 陰性では 20 例 $(20 / 53: 38 \%$ ) で有意差を認めな かった. 3 年膀胱内非再発率は $61 \%$ であった. 単変量解析では膀胱生検ではなく, 病期 $(\mathrm{p}=0.03)$ と脈 管侵襲（ $\mathrm{p}=0.02 ）$ が膀胱内非再発率に対する有意な予後因子であったが, Cox の比例ハザードモデルに よる多変量解析では有意な予後因子ではなかった。

（結論）腎孟尿管腫瘍に対する膀胱生検は膀胱癌合併歴のある症例の上皮内癌や異形成といった随伴 病変の発見に有用であった. 膀胱生検の結果は術後膀胱内再発の予測因子とはならなかった. これは再 発予防の膀胱内追加治療により生検陽性例での再発率が低下した可能性も考えられた.

キーワード : 腎孟尿管腫瘍, 膀胱粘膜多部位生検, 膀胱内再発

\section{緒 言}

膀胱腫瘍症例では肉眼的に正常な膀胱粘膜の生検に よって約 $10 \%$ の症例で随伴する上皮内癌が偶然発見 され，予後不良因子の同定に有用であると報告されて いる ${ }^{1)}$. 一方で尿細胞診は高悪性度の膀胱腫瘍や上皮 内癌で陽性になる頻度が高く，これらの腫瘍は随伴病 変を伴うことが多いことも知られている233. このよう な背景から, 現在のところ膀胱粘膜多部位生検(以下, 膀胱生検）は尿細胞診陽性である膀胱腫瘍症例に適応 があるとされている233.

腎孟尿管腫瘍は比較的予後不良な疾患で尿細胞診陽 性率が $41 \sim 79 \%$, また術前から術後を通じて膀胱腫瘍 を 40〜 $51 \%$ と比較的高率に合併することが知られて いる ${ }^{4}$. 特に術後 $23 \sim 34 \%$ にみられる膀胱内再発は腫 瘍細胞の播種が一つの原因と考えられていて, 腎孟尿 管腫瘍の異型度, 病期や多発性などとの関連が報告さ れている ${ }^{5 / 6)}$. また腎孟・尿管腫瘍症例の詳細なマッピ ング標本での検討によると, 肉眼的には異常を認めな い膀胱に上皮内癌や異型粘膜の存在することが顕微鏡 的に確認できると報告されている77.

以上から，腎孟尿管腫瘍症例(特に尿細胞診陽性例) においても膀胱内に肉眼的病変がなくても膀胱生検に よる随伴病変の評価は意義があると考えられるが, わ れわれが調べ得たかぎりこれを検討した報告はない.

今回, 当科で経験した腎孟尿管腫瘍症例における膀胱 内随伴病変や術後膀胱内再発に対する膀胱生検の有用 性・意義について検討したので報告する．

\section{対象および方法}

症例は 1990 年〜2003 年に当科で手術を施行した 59 例を対象とした. 年齢は 42〜91 歳 (中央值 68 歳), 男 性 41 例, 女性 18 例であった. 手術方法は腎尿管全摘 除術 55 例, 尿管部分切除 - 尿管膀胱新吻合術 2 例, 尿
管鏡下切除術 2 例であった。当科では腎尿管全摘除術 の前に経尿道的に尿管口, 壁内尿管を切除しており, 膀胱生検はそれと同時に施行した. 壁内尿管の処理と して尿管引き抜き法ではなく, high grade 症例や下部 尿管腫瘍に対しても経尿道的切除後に膀胱外からの操 作で腎・尿管を一塊にして摘出している．生検部位は 肉眼的に異常のない粘膜をランダムに原則 5 力所（三 角部, 後壁, 左・右側壁, 頂部) について行った。 そ のうち少なくとも 1 力所以上に癌または異形成を認め た場合を生検陽性とし, それ以外は陰性と判定した。 病理学的所見は, 腎孟・尿管癌取り扱い規約 (第 2 版, 2002 年), 膀胱癌取り扱い規約（第 3 版, 2001 年）に 従った. 膀胱腫瘍を合併した症例は 30 例で, その内訳 は腎孟尿管腫瘍手術時に先行 9 例（そのうち 5 例が後 発), 同時 7 例 (そのうち 2 例が後発), 後発のみ 14 例であった，起算日は手術日とし，最終判定日は 2004 年 12 月 31 日とした. 術後膀胱内非再発率の算定には, Kaplan-Meier 法を用い, 有意差の検定は Log-rank test にて行った．また膀胱生検陽・陰性例に関する各因子 についての 2 群間の独立性の検定は $\chi^{2}$ (または Fisher の直接確率法) 検定により行った. 観察期間は 4〜143 カ月 (中央值 54 力月) であった. 統計解析ソフ トは Stat view 5.0 を使用した.

\section{結 果}

腎孟尿管腫瘍 59 例の各臨床・病理学的因子につい ては Table 1 の如くである.

膀胱生検陽性例は 6 例 (10.2\%) で, その内訳は上皮 内癌が 3 例と異形成が 3 例であった (Table 2 ). 上皮内 癌 3 例のうち 1 例は膀胱癌の既往があり, BCG を膀胱 内注入しても 31 力月間に再発を 3 回繰り返した. 残り の 2 例は手術時に膀胱癌を合併していて, 再発予防と して希望により BCG ではなく副作用の比較的軽いピ 
Table 1 Patient's characteristics according to result of random bladder biopsy

\begin{tabular}{|c|c|c|c|c|c|}
\hline \multirow{2}{*}{\multicolumn{2}{|c|}{ Factor }} & \multirow{3}{*}{$\begin{array}{c}\text { Number (\%) } \\
13(22.0) \\
46(78.0)\end{array}$} & \multicolumn{2}{|c|}{ Random biopsy } & \multirow{3}{*}{$\begin{array}{l}\mathrm{p} \text { value } \\
>0.999\end{array}$} \\
\hline & & & \multirow{2}{*}{$\begin{array}{c}\text { Positive (\%) } \\
1(16.7) \\
5(83.3)\end{array}$} & \multirow{2}{*}{$\begin{array}{c}\text { Negative (\%) } \\
12(22.6) \\
41(77.4)\end{array}$} & \\
\hline Cytology & $\begin{array}{l}\text { Negative (I II III) } \\
\text { Positive (IV V) }\end{array}$ & & & & \\
\hline Tumor location & $\begin{array}{l}\text { Intramural ureter } \\
\text { Others }\end{array}$ & $\begin{array}{ll}13 & (22.0) \\
46 & (78.0)\end{array}$ & $\begin{array}{ll}3 & (50.0) \\
3 & (50.0)\end{array}$ & $\begin{array}{ll}10 & (18.9) \\
43 & (81.1)\end{array}$ & 0.114 \\
\hline Tumor number & $\begin{array}{l}\text { Single } \\
\text { Multiple }\end{array}$ & $\begin{array}{ll}47 & (79.7) \\
12 & (20.3)\end{array}$ & $\begin{array}{ll}3 & (50.0) \\
3 & (50.0)\end{array}$ & $\begin{aligned} 44 & (83.0) \\
9 & (17.0)\end{aligned}$ & 0.092 \\
\hline Tumor shape & $\begin{array}{l}\text { Papillary } \\
\text { Non-papillary }\end{array}$ & $\begin{array}{ll}36 & (61.0) \\
23 & (39.0)\end{array}$ & $\begin{array}{ll}4 & (66.7) \\
2 & (33.3)\end{array}$ & $\begin{array}{ll}32 & (60.4) \\
21 & (39.6)\end{array}$ & $>0.999$ \\
\hline Grade & $\begin{array}{l}\text { G1 \& G2 } \\
\text { G3 }\end{array}$ & $\begin{array}{ll}42 & (71.2) \\
17 & (28.8)\end{array}$ & $\begin{array}{ll}4 & (66.7) \\
2 & (33.3)\end{array}$ & $\begin{array}{ll}38 & (71.7) \\
15 & (28.3)\end{array}$ & $>0.999$ \\
\hline Stage & $\begin{array}{l}\text { pTa \& } 1 \\
\text { pT2 \& } 3 \& 4\end{array}$ & $\begin{array}{ll}27 & (45.8) \\
32 & (54.2)\end{array}$ & $\begin{array}{ll}2 & (33.3) \\
4 & (66.7)\end{array}$ & $\begin{array}{ll}25 & (47.2) \\
28 & (52.8)\end{array}$ & 0.678 \\
\hline INF & $\begin{array}{l}\alpha \& \beta \\
\gamma\end{array}$ & $\begin{array}{ll}48 & (81.4) \\
11 & (18.6)\end{array}$ & $\begin{array}{ll}5 & (83.3) \\
1 & (16.7)\end{array}$ & $\begin{array}{ll}43 & (81.1) \\
10 & (18.9)\end{array}$ & $>0.999$ \\
\hline ly & $\begin{array}{l}0 \\
1\end{array}$ & $\begin{array}{ll}39 & (66.1) \\
20 & (33.9)\end{array}$ & $\begin{array}{ll}3 & (50.0) \\
3 & (50.0)\end{array}$ & $\begin{array}{ll}36 & (67.9) \\
17 & (32.1)\end{array}$ & 0.398 \\
\hline $\mathrm{v}$ & $\begin{array}{l}0 \\
1\end{array}$ & $\begin{array}{ll}46 & (78.0) \\
13 & (22.0)\end{array}$ & $\begin{array}{ll}4 & (66.7) \\
2 & (33.3)\end{array}$ & $\begin{array}{ll}42 & (79.2) \\
11 & (20.8)\end{array}$ & 0.605 \\
\hline Rec. of postop. BT & $\begin{array}{l}\text { Absent } \\
\text { Present }\end{array}$ & $\begin{array}{ll}38 & (64.4) \\
21 & (35.6)\end{array}$ & $\begin{array}{ll}5 & (83.3) \\
1 & (16.7)\end{array}$ & $\begin{array}{ll}33 & (62.3) \\
20 & (37.7)\end{array}$ & 0.407 \\
\hline Past \& concur. his. of BT & $\begin{array}{l}\text { Absent } \\
\text { Present }\end{array}$ & $\begin{array}{l}44(74.6) \\
15(25.4)\end{array}$ & $\begin{array}{ll}2 & (33.3) \\
4 & (66.7)\end{array}$ & $\begin{array}{ll}42 & (79.2) \\
11 & (20.8)\end{array}$ & $\underline{0.032}$ \\
\hline
\end{tabular}

Rec. of postop. BT : Recurrence of postoperative bladder tumor

Past \& concur. his. of BT : Past and concurrent history of bladder tumor

ラルビシンを膀胱内注入され，それぞれ 22,28 カ月再 発を認めなかった．異形成 3 例のうち 1 例は手術時に 膀胱癌を合併し, 多発していたので再発予防として BCG が膀胱内注入され, 68 カ月再発を認めなかった. 残りの 2 例は膀胱癌の既往がなく, 膀胱内注入せずに, それぞれ 16,22 力月再発を認めなかった.

各臨床・病理組織学的因子に関して膀胱生検陽/陰 性例について比較すると（Table 1), 尿細胞診（陽/ 陰性), 腫瘍の部位 (膀胱壁内尿管/それ以外), 数 (単/ 多発), 形態(乳頭状/非乳頭状), 異型度 $(\mathrm{G} 1 \cdot 2 / \mathrm{G} 3)$, 病期 (pT1 以下/pT2 以上), ly $(0 / 1), \mathrm{v}(0 / 1)$, 術後 膀腅内再発の有無では膀胱生検陽/陰性例の頻度に有 意差を認めなかった．膀胱癌合併歴例（術前および同 時合併例. 術後膀胱内再発は含まない, 以下同様）で は膀胱生検陽性例の頻度が陰性例より有意に多かった $(\mathrm{p}=0.032)$.

腎孟尿管腫瘍術後膀胱内に再発した症例（観察期間 中央值 54 力月）は 59 例中 21 例 $(35.6 \%)$ で, 非再発 率では 1 年 $69 \%, 2$ 年 $64 \%, 3$ 年 $61 \%$ となり, いずれ
の症例も 3 年以内に再発していた (Fig. 1). 膀胱生検陽 性例（観察期間中央值 28 力月）では 6 例中 1 例 (16.7\%) が術後膀胱内再発し, 陰性例（観察期間中央 值 55 力月）は 53 例中 20 例（37.7\%）であり有意差を 認めなかった $(p=0.407)$. 生検結果別での 3 年膀胱内 非再発率は陽性例で $83 \%$, 陰性例で $59 \%$ と有意差は なく（ $\mathrm{p}=0.297 ）$ むしろ陽性例のほうが再発率は低 かった (Fig. 1).

術後膀胱内再発に関して各臨床・病理組織学的因子 について検討したところ (Table 3), 単変量解析では尿 細胞診 (陽/陰性), 腫瘍の部位 (膀胱壁内尿管/それ以 外), 数 (単/多発), 形態 (乳頭状/非乳頭状), 異型度 $(\mathrm{G} 1 \cdot 2 / \mathrm{G} 3), \operatorname{ly}(0 / 1)$, 膀胱生検 (陽/陰性), 膀胱癌 合併歴の有無には有意差を認めなかったが, high stage $(\mathrm{p}=0.031)$, 脈管侵襲あり群 $(\mathrm{p}=0.020)$ のほう が有意に再発率が低い傾向を認めた. さらに, Table 3 のすべての因子を含めて多変量解析を行ったとこ ろ, 有意な因子は認めなかった. 


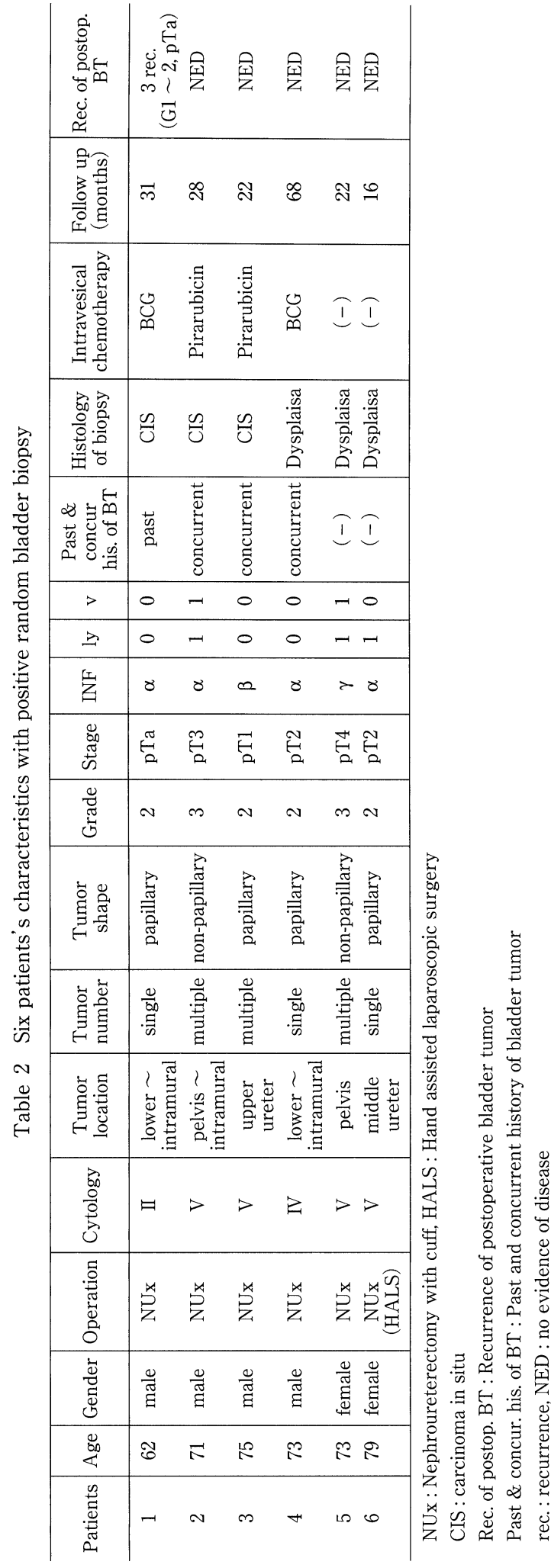

\section{考察}

膀胱腫瘍に対する膀胱生検は約 20〜 25\% の症例で 異形成や上皮内癌といった膀胱内の随伴病変を発見す ることができると報告されている 胞診陽性例や非乳頭状腫湯例とされ，特に膀胱鏡にて も発見困難な上皮内癌や異形成の発見に有用とされて いる ${ }^{2) 31}$. 一方, 単発で乳頭状腫瘍例に対しては有益な 情報が得られないことやむしろ播種の危険があるため 適応とされていない23).

今回，腎盂尿管腫瘍症例に対する膀胱生検の有用性 を検討したところ，腎需尿管腫瘍 59 例中 6 例 (10.2\%) の症例に膀胱内の膀胱生検で異形成 (3 例) と上皮内癌 (3 例) が発見された.このうち膀胱癌合併歴のある症 例では 15 例中 4 例 $(26.7 \%)$ と従来の報告と同頻度で あった ${ }^{8)}$. 一方, 膀胱癌合併歴のない症例では膀胱内の 随伴病変は 44 例中異形成が 2 例 $(4.5 \%)$ のみで，上皮 内癌は認めなかった。膀胱生検の各臨床・病理学的因 子を検討したところ (Table 1), 膀胱癌合併歴群だけが 有意 $(\mathrm{p}=0.032)$ に膀胱生検陽性率の頻度が高かった. 以上からは, 膀胱内随伴病変の検出に有用な膀胱生検 は,さらに多数例での検討が必要であるが, 膀胱癌合 併歴群に適応と考えられた，とくに細胞診陰性，膀胱 癌合併歴なし，かつ単発の腎孟尿管腫瘍症例では不要 と思われた。

腎孟・尿管腫瘍症例の膀胱内再発を予測する因子と して従来から臨床・病理学的因子の検討がなされてい るが, 異型度, 病期や多発性との関連が報告されてい

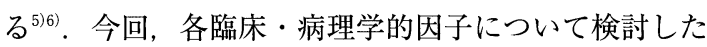
ところ (Table 3), 単変量解析では異型度や多発性には 有意差を認めなかったが，病期と脈管侵襲が有意な因 子であった。しかし多変量解析では有意差を認めな かった. Low grade, low stage で膀胱内再発が高くな るとの報告もあるが516)，今回の検討は少数例であり， 脈管侵襲についても多数例での検討が必要と考えられ た.一方で今回の検討目的である膀胱生検については, 膀胱内再発の予測因子として有意差を認めず，むしろ 逆に陽性例のほうが院性例よりも再発率が低下すると いう結果であった.この原因の一つの可能性として, 陽性例に対しては 6 例中 4 例に再発予防のため膀胱内 注入療法が施行されており (Table 2$)$, 膀胱内注入療法 の影響も否定できないものと考えられる.

いずれにしろ今回の検討では腎盂尿管腫瘍術後の膀 胱内再発 $35.6 \%$ の症例に認められ, いずれも 3 年以内 の再発であることから, 少なくともこの期間は膀胱鏡 
Fig. 1 Bladder recurrence free rate of 59 patients with renal pelvic and ureteral tumor according to result of random bladder biopsy

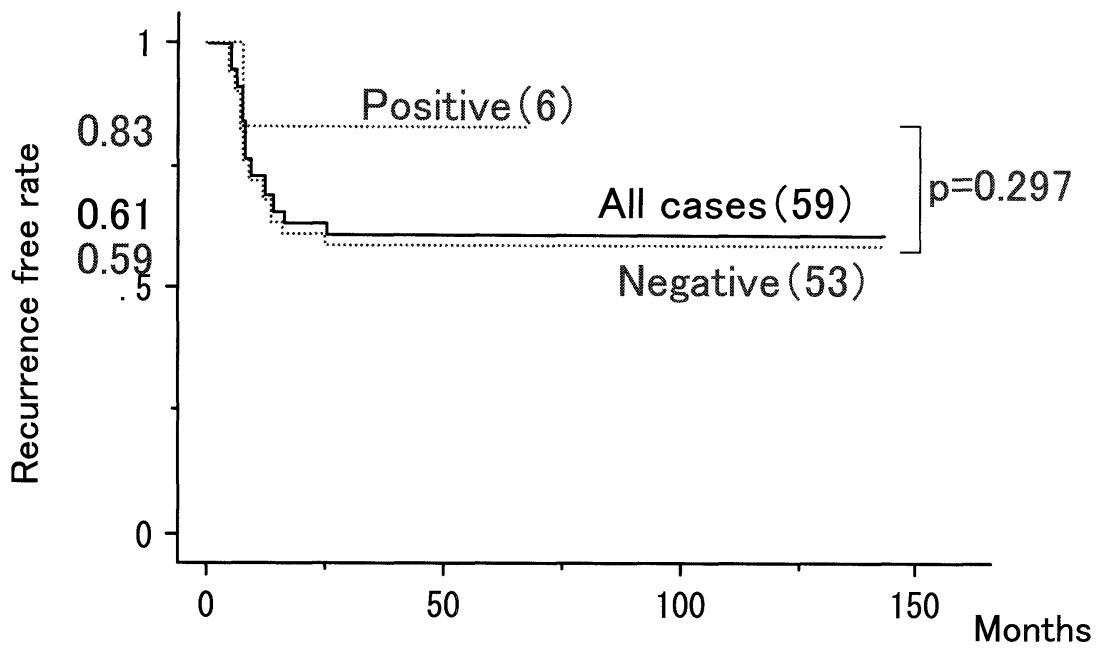

Table 33 year bladder recurrence free rate and, Uni- and mutivariate analysis according to clinical and pathological factors

\begin{tabular}{|c|c|c|c|c|}
\hline Factor & & $\begin{array}{c}3 \text { year recurrence } \\
\text { free rate }(\%)\end{array}$ & $\begin{array}{l}\text { Univariate } \\
\text { p value }\end{array}$ & $\begin{array}{l}\text { Multivariate } \\
\text { p value }\end{array}$ \\
\hline Cytology & $\begin{array}{l}\text { Negative (I II III) } \\
\text { Positive (IV V) }\end{array}$ & $\begin{array}{l}36.9 \\
69.3\end{array}$ & 0.066 & 0.117 \\
\hline Tumor location & $\begin{array}{l}\text { Intramural ureter } \\
\text { Others }\end{array}$ & $\begin{array}{l}50.0 \\
63.4\end{array}$ & 0.519 & 0.184 \\
\hline Tumor number & $\begin{array}{l}\text { Single } \\
\text { Multiple }\end{array}$ & $\begin{array}{l}60.8 \\
63.6\end{array}$ & 0.856 & 0.954 \\
\hline Tumor shape & $\begin{array}{l}\text { Papillary } \\
\text { Non-papillary }\end{array}$ & $\begin{array}{l}53.9 \\
72.2\end{array}$ & 0.189 & 0.760 \\
\hline Grade & $\begin{array}{l}\text { G1 \& G2 } \\
\text { G3 }\end{array}$ & $\begin{array}{l}56.2 \\
74.5\end{array}$ & 0.240 & 0.968 \\
\hline Stage & $\begin{array}{l}\text { pTa \& } 1 \\
\text { pT2 \& } 3 \& 4\end{array}$ & $\begin{array}{l}44.4 \\
76.5\end{array}$ & $\underline{0.031}$ & 0.584 \\
\hline INF & $\begin{array}{l}\alpha \& \beta \\
\gamma\end{array}$ & $\begin{array}{l}57.6 \\
80.0\end{array}$ & 0.267 & 0.904 \\
\hline ly & $\begin{array}{l}0 \\
1\end{array}$ & $\begin{array}{l}56.7 \\
72.2\end{array}$ & 0.399 & 0.090 \\
\hline $\mathrm{v}$ & $\begin{array}{l}0 \\
1\end{array}$ & $\begin{array}{l}52.0 \\
92.3\end{array}$ & $\underline{0.020}$ & 0.064 \\
\hline Random bladder biopsy & $\begin{array}{l}\text { Negative } \\
\text { Positive }\end{array}$ & $\begin{array}{l}58.5 \\
83.3\end{array}$ & 0.297 & 0.205 \\
\hline Past \& concur. his. of BT & $\begin{array}{l}\text { Absent } \\
\text { Present }\end{array}$ & $\begin{array}{l}65.1 \\
50.0\end{array}$ & 0.322 & 0.649 \\
\hline
\end{tabular}

Past \& concur. his. of BT : Past and concurrent history of bladder tumor 
による十分な経過観察が必要であることが示された. また, 膀胱癌合併歴群に対する膀胱生検は随伴病変の 発見に有意義と思われるが, 膀胱内再発の予測因子と しての意義は自験例では膀胱内注入療法の影響も否定 出来ないことから, 今後の検討が必要と考えられた.

結 語

腎孟尿管腫瘍に対する膀胱生検は

1. 膀胱癌合併歴のある症例の上皮内癌や異形成と いった随伴病変の発見に有用であった.

2. 術後膀胱内再発の子測因子とはならなかったが, 膀胱内注入療法の影響も否定出来ず，今後の検討が必 要である.

本論文の要旨は第 55 回日本泌尿器科学会中部総会で発 表した.

\section{文献}

1) May F, Treiber U, Hartung R, Schwaibold H : Significance of random bladder biopsies in superficial bladder cancer. Eur Urol., 44, 47-50, 2003.

2) Oosterlinck W, Lobel B, Jakse G, Malmstrom PU, Stockle M, Sternberg C : European Association of Urology (EAU) Working Group on Oncological Urology : Guidelines on bladder cancer. Eur Urol., 41, 105-12, 2002.
3) van der Meijden AP, Sylvester R, Oosterlinck W, Solsona E, Boehle A, Lobel B, Rintala E; for the EAU Working Party on Non Muscle Invasive Bladder Cancer: EAU guidelines on the diagnosis and treatment of urothelial carcinoma in situ. Eur Urol., 48, 363-71, 2005.

4）辻本裕一, 小森和彦, 佐藤元孝, 高田 剛, 本多正 人, 松宮清美, 藤岡秀樹 : 腎孟尿管腫瘍の臨床的検 討. 日泌尿会誌, 97, 642-8, 2006.

5) Hisataki T, Miyao N, Masumori N, Takahashi A, Sasai M, Yanase M, Itoh N, Tsukamoto T : Risk factors for the development of bladder cancer after upper tract urothelial cancer. Urology, 55, $663-7,2000$.

6) Bloom NA, Vidone RA, Lytton B : Primary carcinoma of the ureter : a report of 102 new cases. J Urol., 103, 590-8, 1970.

7) Kakizoe T, Fujita J, Murase T, Matsumoto K, Kishi K : Transitional cell carcinoma of the bladder in patients with renal pelvic and ureteral cancer. J Urol., 124, 17-9, 1980.

8) Althausen AF, Prout GR Jr, Daly JJ : Non-invasive papillary carcinoma of the bladder associated with carcinoma in situ. J Urol., 116, 575—80, 1976.

(2006 年 2 月 2 日受付, 5 月 17 日受理) 